\title{
MATHEMATIKA
}

A JOURNAL OF PURE AND APPLIED MATHEMATICS

Edited by

H. DAVENPORT, W. R. DEAN,

C. A. ROGERS, J. G. SEMPLE

VOLUME 6

1959

Published by

THE DEPARTMENT OF MATHEMATICS

UNIVERSITY COLLEGE

LONDON 
Printed by

C. F. HODGSON \& SON, LTD.

23 PAKENHAM STREET

LONDON, W.C.1 


\section{INDEX TO VOLUME 6}

Page

BARTON, D. E. and DAVID, F. N. Combinational extreme value distributions $\quad$.. 63

$\begin{array}{llllllllll}\text { BESICOVITCH, A. S. Rational polygons } & \text {. } & \text { R } & \ldots & \ldots & \ldots & \ldots & \ldots & 98\end{array}$

COHN, P. M. Simple rings without zero-divisors, and Lie division rings $\quad \ldots \quad$. $\quad 14$

COLLINS, W. D. On the solution of some axisymmetric boundary value problems by means of integral equations, II: further problems for a circular disc and a $\begin{array}{llllllllllll}\text { spherical cap } & . . & \ldots & \ldots & \ldots & \ldots & \ldots & \ldots & \ldots & \ldots & \ldots & 120\end{array}$

COXETER, H. S. M., FEW, L. and ROGERS, C. A. Covering space with equal spheres 147 DAVID, F. N. See Barton, D. E.

DEAN, W. R. and HURST, J. M. Note on the motion of fluid in a curved pipe .. 77 FRÖHLICH, A. The genus field and genus group in finite number fields $\quad \ldots \quad \ldots \quad 40$

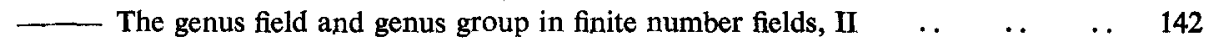
FEW, L. See COXETER, H. S. M.

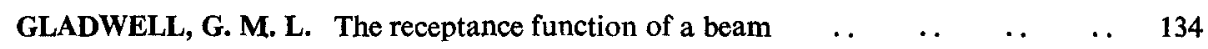
HOCKING, L. M. and MICHAEL, D. H. The stability of a column of rotating liquid 25 HURST, J. M. See DEAN, W. R.

JAMES, 1. M. Products on spheres ..

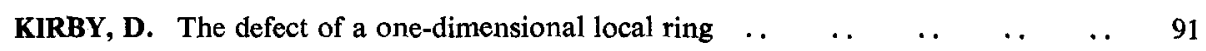

MICHAEL, D. H. See Hocking, L. M.

NORTHCOTT, D. G. The reduction of a one-dimensional local ring .. $\quad \ldots \quad \ldots \quad \ldots \quad 87$

$\begin{array}{lllllllllll}\text { ROGERS, C. A. Lattice coverings of space } & \ldots & \ldots & \ldots & \ldots & \ldots & \ldots & 33\end{array}$

See CoxeTRR, H. S. M.
SHAIL, R. Two centred expansion of the retarded Green's function ...

SNEDDON, I. N. A note on the axially symmetrical punch problem $\ldots \quad \ldots \quad \ldots \quad \ldots \quad 118$

STONE, A. Cardinals of closed sets ..

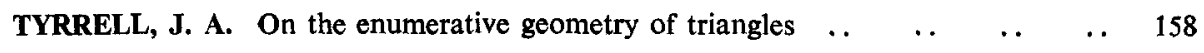

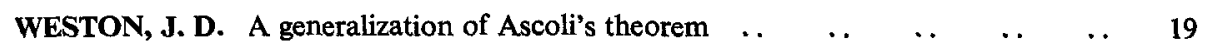

YACOUB, A. R. Elastic equilibrium of completely aeolotropic cylinders : extension by

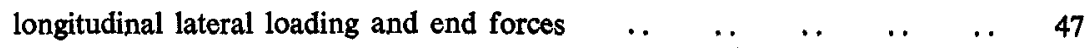

